\title{
The Experience of Turkish Economy on Tax Smoothing
}

\author{
Asst. Prof. Dr. Cevat Bilgin (Çukurova University, Turkey) \\ Ph.D. Candidate Handan Kaynar Bilgin (Çukurova University, Turkey)
}

\begin{abstract}
Absract
Taxes lead a deadweight loss and this deadweight loss increases with the tax rate. The main objective of the government should be deciding the tax rate which minimizes the deadweight loss. The planned tax rate is constant or the expected tax rate is the same as the current tax rate. The 'random walk test' of the tax smoothing hypothesis comes out by the fact that changes in the tax rate should be unpredictable. In other words, tax smoothing hypothesis implies that a tax rate has random walk behavior, but this behavior is not sufficient condition for tax smoothing. In this paper, a direct test of tax smoothing is presented; if future tax rate is cointegrate with the current permanent government expenditure rate, the tax smoothing hypothesis holds. By using this test, it is possible to differentiate among 'strong tax smoothing', 'weak tax smoothing' and 'no-tax smoothing'. Application of this test to Turkey shows evidence in support of weak form of tax smoothing.
\end{abstract}

\section{Introduction}

The main points of tax smoothing are expressed in Barro (1979). According to this article, the marginal welfare cost of taxation is an increasing function of the tax rate. Therefore, the ideal tax program is to set a permanently fixed tax rate that will generate revenue over time. Besides, it was assumed that the time path of government's tax revenue is determined by exogenously given government expenditure and an initial amount of debt. Taxes lead a deadweight loss and this deadweight loss increases more than proportionately with the tax rate. Deciding the tax rate which minimizes the deadweight loss should be the main objective of the government. This optimization is constrained by the present value borrowing. So the planned tax rate is constant under certainty or the expected tax rate is the same as the current tax rate under uncertainty. The 'random walk test' of the tax smoothing hypothesis comes out by the fact that changes in the tax rate should be unpredictable as they reflect only the new information on the time path of government expenditure, output, and other variables.

There are at least two reasons to go beyond the random-walk tests of tax-smoothing models. Ghosh (1995) argues that it is often difficult to reject the null hypothesis of a random walk for many economic time series in finite samples. Thus such tests may have very low power. Besides, even if tax rates follow a random walk, this does not necessarily imply that governments smooth taxes. Tax smoothing is only one of many possible explanations for unpredictable tax-rate changes.

Specifically, the tax smoothing hypothesis implies that future expectations of changes in government expenditure determine whether it is optimal for a government to run either budget surpluses or deficits in the present period. According to the tax smoothing hypothesis, it can be optimal for a government to run budget surpluses as well as deficits as long as they are justified by future expectations of changes in government expenditure. The tax smoothing hypothesis implies that when a government expects a future increase in its expenditure, it increases the tax rate today and runs a budget surplus (smaller deficit). Conversely, when the government expects a future decrease in expenditure, it lowers the tax rate today and runs a budget deficit (smaller surplus). This behavior can be explained by the fact that the government wishes to smooth the tax rate over time in order to minimize the implied distortionary welfare costs of taxation. As a consequence, when the tax smoothing hypothesis is true, the expected tax rate is constant over time, or, in more formal terms, the tax rate follows a martingale (Adler, 2006 and Reitschuler, 2010).

According to the study of Davis and Fabling (2002), if assets accumulated under a tax smoothing policy earn an average return more than the government's cost of borrowing, then tax smoothing minimizes the excess burden compared to a balanced budget policy. Therefore, it is advisable to examine whether countries actually follow tax smoothing fiscal policies. The optimal tax rate based on the tax smoothing hypothesis is a constant (or a smoothly changing one) if policy makers are concerned about minimizing the distortionary effects of taxation. Jayawicrama and Abeysinghe (2013) point out that testing whether the tax rate follows a random walk does not necessarily support the tax smoothing hypothesis.

Sahasakul (1986) presented a direct test for the tax smoothing hypothesis. The test implies that tax rate is related to the permanent component of the government expenditure rate. He found evidence against the tax smoothing hypothesis by regressing the US current marginal tax rate on the permanent and transitory components of the government expenditure rate and some other variables. It is difficult to measure permanent expenditure and income. Therefore, some researchers have preferred the other aspects of the tax smoothing hypothesis. They analyze whether the fiscal deficit is informative about future changes in government expenditures (Huang and Lin, 1993; Ghosh, 1995; Olekalns, 1997; Serletis and Schorn, 1999; Cashin et al., 2002; Niepelt, 2002). Huang and Lin (1993) find that the tax smoothing hypothesis (TSH) is rejected for the United States for the period 1947-1988 but not for 1929-1988. Ghosh (1995) finds that the TSH cannot be 
rejected for Canada and the United States for 1962-1988 and 1961-1988. Olekalns (1997) rejects the TSH when applied to Australian data for the period 1964/1965 to 1994/1995. Olekalns and Crosby (1998) test the TSH for Australia, the United Kingdom and the United States; they find that tax smoothing cannot be rejected only for the latter. Cashin et al. (1998, 1999) test the TSH for India, Pakistan and Sri Lanka, respectively; they find that the TSH is rejected only in the case of Sri Lanka. The others impose unit root and cointegration by using government revenue and expenditure series to test the tax smoothing hypothesis (Strazicich, 2002; Adler, 2006; Lusinyan and Thronton, 2009, 2011; Reitschuler, 2010; Pasten and Cover, 2011). Adler (2006), which tests the TSH for Sweden, finding that tax smoothing is rejected for the period 1970-1996 but not for 1952-1999. These studies do not give a direct test of the tax smoothing hypothesis like in Sahasakul.

In this paper, we refer to the study of Jayawicrama and Abeysinghe (2013) for the testing TSH. As a model, we regress the tax rate on the permanent component of the government expenditure rate. By using this regression, we derive a direct testing of the tax smoothing hypothesis. If the tax rate and permanent component of the government expenditure rate are perfectly correlated, they have the cointegrating relation.

\section{The Model}

Government expenditure rate is defined as the ratio of total government expenditure to income. The extracted unit root component from this rate is called permanent government expenditure rate. Average government revenue rate as a proxy of marginal tax rate is characterized as the ratio of tax revenue to income; and we call it simply as the tax rate. We then set the tax rate equal to the permanent government expenditure rate as in Jayawicrama and Abeysinghe (2013).

$$
\tau_{t}=g_{t}^{p}
$$

where $\tau_{t}$ and $g_{t}^{p}$ refer to the tax rate and the permanent government expenditure rate respectively. The martingale property of the tax rate implies

$$
\tau_{t+1}=\tau_{t}+\varepsilon_{t+1}
$$

Thus we have,

$$
\tau_{t+1}=g_{t}^{p}+u_{t+1}
$$

where $u_{t+1}$ absorbs the transitory components.

The equation (3) can be written in testable form as

$$
\tau_{t}=\beta g_{t-1}^{p}+u_{t}
$$

where $\beta$ is expected to be unity, $u_{t}=\rho u_{t-1}+\varepsilon_{t}$ and $\varepsilon_{t}$ is assumed to be zero mean white nosie process.

The autocorrelation parameter $\rho$ measures the degree of cointegration. (Rajaguru and Abeysinghe, 2008). If the tax smoothing hypothesis holds, Equation (4) yields a case where two random walks cointegrate. The equation (4) includes transitory components. The three cases can be defined: (i) If $\rho=0$, it is the highest degree of cointegration that implies the strong tax smoothing. (ii) If $0<\rho<1$, it is the low degree of cointegration implying the weak tax smoothing. (iii) If $\rho=1$, there is no cointegration that implies the rejecting the tax smoothing hypothesis even if the tax rate follows a random walk.

The Error Correction Model (ECM) developed by Jayawicrama and Abeysinghe (2013) to assess the presence of tax smoothing is

$$
\Delta \tau_{t}=\theta_{0}+\theta^{\prime} x_{t-1}+\lambda_{1} g_{t-1}^{t}+\lambda_{2} g_{t-2}^{p}+\alpha_{1}\left(\tau_{t-1}-g_{t-2}^{p}\right)+\varepsilon_{t}
$$

Where $g_{t-1}^{t}$ is the one lagged of transitory component, $x_{t-1}$ is a vector of exogenous variables imposing transitory effects on the future tax rates. The tax smoothing hypothesis holds if $\theta_{0}=\theta^{\prime}=\lambda_{1}=\lambda_{2}=0$ and $\alpha_{1} \neq 0$. If $\alpha_{1}=-1$, then we have the strong version of tax smoothing. If $0 \prec \alpha_{1} \prec 1$, then we have the weak tax smoothing. If $\alpha_{1}=0$, then the tax smoothing hypothesis does not hold.

\section{Empirical Results}

We use the annual data for the period of 1950-2012 to analyze the tax smoothing experience on Turkey. The tax rate is derived by the ratio of tax revenue to income and it is denoted by $\tau_{t}$. The expenditure rate is the ratio 
of total government expenditure to income and it is denoted as $g_{t}$. Figure 1 shows the tax rate and government expenditure rate over the sample period. The tax rate and the government expenditure rate seem to have stochastic trend. This implies that both of the series have unit roots. Moreover, it looks like that there is a long run relation between them.

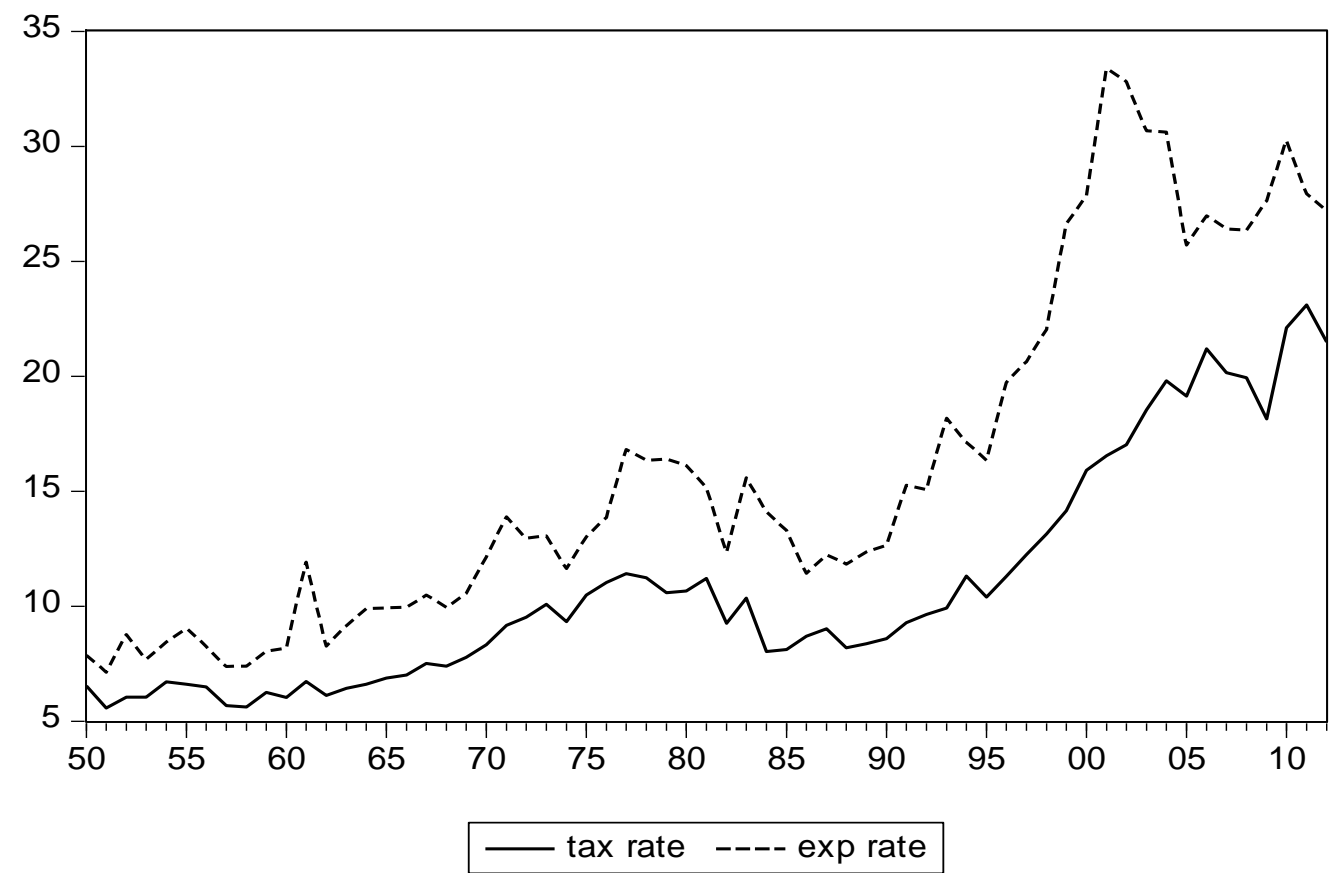

Figure 1. Actual Tax Rate and Government Expenditure Rate

Permanent component of the government expenditure rate, $g_{t}^{p}$, is extracted from $g_{t}$ by using two methods. The first one is known as the Beveridge-Nelson (BN) decomposition method presented by Beveridge and Nelson (1981). Firstly, we estimate the Autoregressive Integrated Moving Average model, ARIMA (p, d, q). We derived the appropriate ARIMA $(2,1,2)$ model for the expenditure rate. Then, we decomposed the series as the unit root component and the transitory component by using the BN method in Eviews. The components are denoted by $B N g_{t}^{p}$ and $B N g_{t}^{t}$ respectively. The second method of deriving the permanent expenditure rate is Kalman Filter smoothing method. The smooth component is taken as the permanent component. (Hamilton, 1994) We derived the smoothed series of the expenditure rate by using the Gretl package program and denoted it as $K F g_{t}^{p}$. The difference between the actual series and the smooth series is defined as the transitory component, $K F g_{t}^{t}$.

\begin{tabular}{|l|c|c|}
\hline Variables & Level $^{\text {a }}$ & First Difference $^{\mathbf{b}}$ \\
\hline Actual data & $-0.995(1)$ & $-5.119(1) * *$ \\
\hline Tax rate $\left(\tau_{\mathrm{t}}\right)$ & $-0.611(1)$ & $-4.553(1) * *$ \\
\hline Expenditure rate $\left(\mathrm{g}_{\mathrm{t}}\right)$ & $-15.11(1)^{* *}$ & \\
\hline Decomposed transitory data & \\
\hline $\mathrm{BN} \mathrm{g}_{\mathrm{t}}{ }^{\mathrm{t}}$ & $-8.934(1)^{* *}$ & \\
\hline $\mathrm{KF} \mathrm{g}_{\mathrm{t}}$ &
\end{tabular}

Notes: The values in parentheses are the appropriate lag numbers determined by Schwarz criteria, ${ }^{\mathrm{a}}$ tests include constant, ${ }^{\mathrm{b}}$ tests do not include constant, $*$ denotes significance at the $5 \%$ level, $* *$ denotes significance at the $1 \%$ level.

\section{Table 1. ADF Unit Root Test Results}

Table 1 gives the Augmented Dickey Fuller unit root test results. The tax rate and the expenditure rate have unit roots in levels; they are nonstationary variables. Table 1 implies that the tax rate and the expenditure rate have the property of the random walk with drift. The first differences of the series are stationary, that is the variables are $\mathrm{I}(1)$ series. On the other hand, both of the transitory variables are stationary in levels; they are $\mathrm{I}(0)$ variables. Figure 2 plots $g_{t}$, BN unit root and KF smooth component. It is clear that there is close correspondence between the actual and permanent components. 


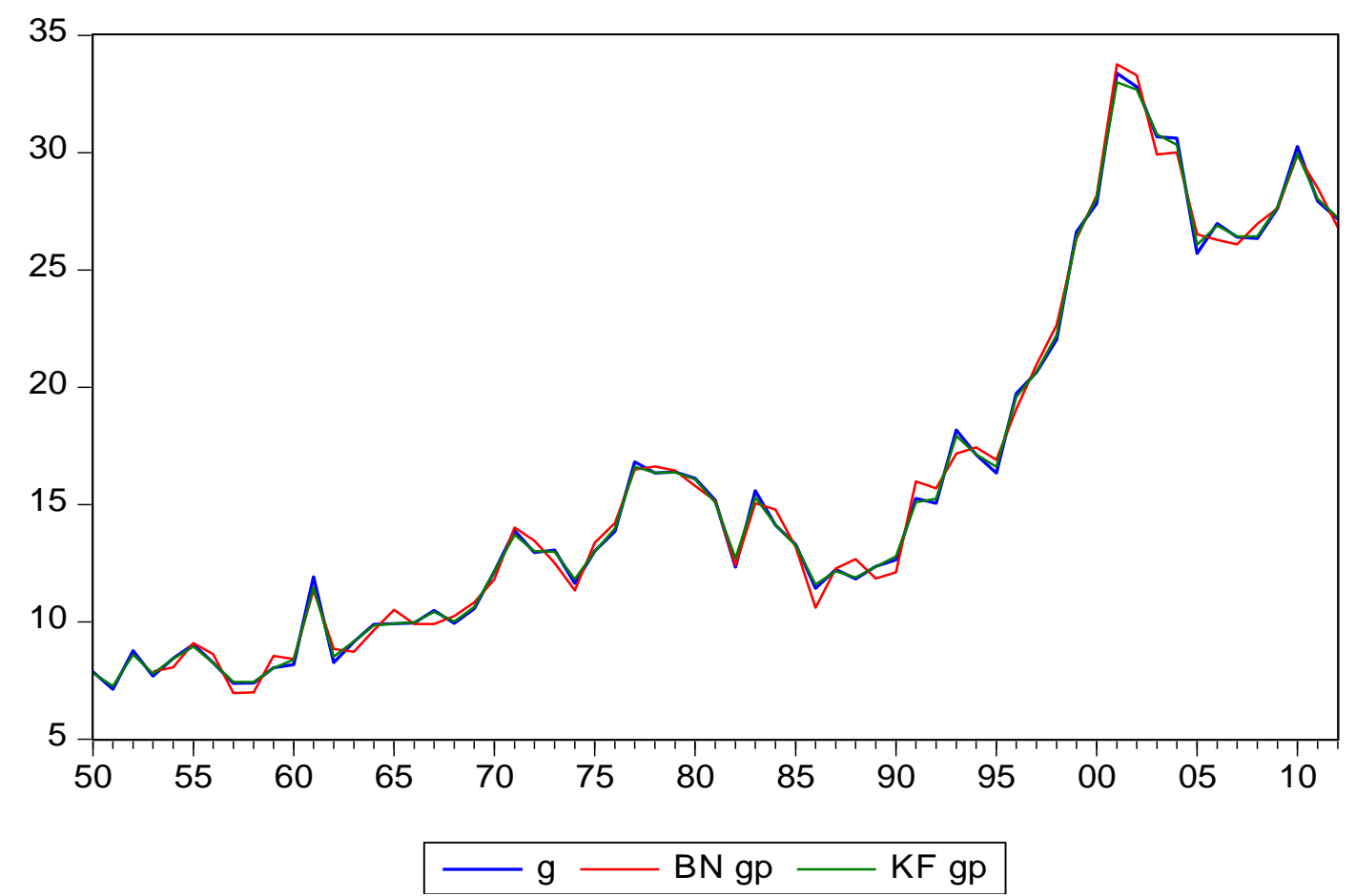

Figure 2. Actual, BN Unit Root and KF Smooth Series of Expenditure Rate

Table 2 demonstrates the Least Square estimation results of the equation 4. We estimated two different equations for each definition of the permanent expenditure rate. The estimates of $\beta$ are very similar but they are less than unity; it is 0.676 for the $\mathrm{BN}$ model and it is 0.679 for the $\mathrm{KF}$ model. The correspondent t-statistics are implying that these estimates are statistically significant.

\begin{tabular}{|l|c|}
\hline Beveridge-Nelson unit root series & 0.676 \\
Coefficient estimate of BNgpt-1 & $(55.07)$ \\
\hline ADF test statistic for residuals & $-3.958^{*}$ \\
\hline Rho $(\rho)$ & 0.559 \\
\hline AR $(2)$ F test & $13.057^{* *}$ \\
\hline Kalman Filtered smooth series & 0.679 \\
\hline Coefficient estimate of BNgpt-1 & $(59.42)$ \\
\hline ADF test statistic for residuals & $-3.819^{*}$ \\
\hline Rho $(\rho)$ & 0.589 \\
\hline AR $(2)$ F test & $17.465^{* *}$ \\
\hline
\end{tabular}

Notes: The values in parentheses are t values. ADF regressions have zero lag and no constant. The Engle-Granger critical value is -3.4 at the $5 \%$ level. $*$ denotes significance at the $5 \%$ level and $* *$ denotes significance at the $1 \%$ level

Table 2. Test for Cointegration between Tax Rate and Permanent Expenditure Rate (Dependent variable is $\tau_{t}$ )

Table 2 shows that the degree of cointegration measured by $\rho$ is not perfect; they are between zero and one. The values of $\rho$ for each model are very similar; it is 0.559 for the BN model and it is 0.589 for the KF model. The unit root tests for the residuals prove that they do not have the unit roots at the $5 \%$ level of significance. This result supports the cointegration for both of the models. The autocorrelation test results imply that the residuals have autocorrelation problem. The autocorrelation problem in the KF model is bigger than the autocorrelation in the BN model.

Money growth rate (gm1) and unemployment rate (ur) are taken as exogenous variables and they reflect the transitory effects on the tax rate. According to the study of Jayawicrama and Abeysinghe (2013), the money growth rate has the seignorage and the inflation effect. Higher inflation and higher nominal incomes push individuals into higher tax brackets. Thus, the growth rate of M1 is expected to have positive effect. The effect of unemployment is related to the social welfare structure. If the social welfare structure is widespread, then the government might have to raise the tax rate to afford the relating services when unemployment increases. On the other hand, even if the social welfare is not extensive, the government may lower the tax rate to enhance economic growth when unemployment increases. 
Table 3 gives the estimation results of the ECM defined by the equation 5. We estimated two different models; the first one includes the Beveridge-Nelson decomposed series and the second one includes the series derived from the Kalman-Filter smoothing method. These models are labeled as the BN model and the KF model. The diagnostic tests show that there are neither autocorrelation-heteroskedasticity problems nor specification bias in the estimated models. The estimated $\alpha_{1}$ values of the BN model and the KF model are -0.225 and -0.197 respectively. The former one is statistically significant at the $1 \%$ level; the latter is statistically significant at the

$5 \%$ level. This result confirms the presence of the cointegration between $\tau_{t}$ and $g_{t-1}^{p}$. The degree of cointegration is lower than required value by the strong version of the tax smoothing hypothesis which is assuming $\alpha_{1}$ is -1 . The estimated coefficients of the money growth have the expected signs but they are insignificant. The negative coefficients of the unemployment rates implies that the tax rates are decreased during the recessionary periods. However, their values are very small and they are not significant. Moreover, the effects of transitory components of the government expenditure rate on the tax rate are not significant in neither of the models.

\begin{tabular}{|c|c|c|c|}
\hline \multicolumn{2}{|l|}{ BN Model } & \multicolumn{2}{|l|}{ KF Model } \\
\hline Explanatory Variable & Estimated Values & Explanatory Variable & Estimated Values \\
\hline Constant & $\begin{array}{l}0.221 \\
(0.69) \\
\end{array}$ & Constant & $\begin{array}{l}0.223 \\
(0.79) \\
\end{array}$ \\
\hline $\mathrm{BNg}_{\mathrm{t}-1}^{\mathrm{t}}$ & $\begin{array}{l}0.054 \\
(0.25) \\
\end{array}$ & $\mathrm{KFg}_{\mathrm{t}-1}^{\mathrm{t}}$ & $\begin{array}{l}-0.965 \\
(-1.60) \\
\end{array}$ \\
\hline$g m 1_{t-1}$ & $\begin{array}{l}0.007 \\
(1.67)\end{array}$ & $\mathrm{gm}_{\mathrm{t}-1}$ & $\begin{array}{l}0.007 \\
(1.76) \\
\end{array}$ \\
\hline $\mathrm{ur}_{\mathrm{t}-1}$ & $\begin{array}{l}-0.038 \\
(-0.54)\end{array}$ & $\mathrm{ur}_{\mathrm{t}-1}$ & $\begin{array}{l}-0.042 \\
(-0.67)\end{array}$ \\
\hline $\mathrm{BNg}_{\mathrm{t}-2}^{\mathrm{p}}$ & $\begin{array}{l}-0.073 \\
(-1.75)\end{array}$ & $\mathrm{KFg}_{\mathrm{t}-2}^{\mathrm{p}}$ & $\begin{array}{l}-0.062 \\
(-1.53)\end{array}$ \\
\hline$\left(\tau_{\mathrm{t}-1}-\mathrm{BNg}_{\mathrm{t}-2}^{\mathrm{p}}\right)$ & $\begin{array}{c}-0.225 * * \\
(-2.96)\end{array}$ & $\left(\tau_{\mathrm{t}-1}-\mathrm{KFg}_{\mathrm{t}-2}^{\mathrm{p}}\right)$ & $\begin{array}{c}-0.197 * \\
(-2.57)\end{array}$ \\
\hline \multicolumn{2}{|l|}{ Diagnostic Tests } & \multicolumn{2}{|l|}{ Diagnostic Tests } \\
\hline $\mathrm{R}^{2}$ & 0.463 & $\mathrm{R}^{2}$ & 0.470 \\
\hline $\operatorname{AR}(2) \mathrm{F}$ test & $\begin{array}{l}2.195 \\
{[0.12]}\end{array}$ & $\operatorname{AR}(2) \mathrm{F}$ test & $\begin{array}{c}1.191 \\
{[0.31]}\end{array}$ \\
\hline Heteros F test & $\begin{array}{l}1.657 \\
{[0.15]}\end{array}$ & Heteros F test & $\begin{array}{l}2.123 \\
{[0.07]}\end{array}$ \\
\hline Reset F test & $\begin{array}{l}1.977 \\
{[0.15)}\end{array}$ & Reset F test & $\begin{array}{l}2.715 \\
{[0.08]}\end{array}$ \\
\hline
\end{tabular}

Notes: The values in parentheses are t values; the values in brackets are diagnostic p-values. * denotes significance at the $5 \%$ level and $* *$ denotes significance at the $1 \%$ level. Pulse dummy variable is used for 2010.

Table 3. ECM for Testing on Tax Smoothing (Dependent Variable is $\Delta \tau_{t}$ )

\section{Conclusion}

The general conclusion derived from the empirical analysis is that Turkey has followed a weak tax smoothing. Taxes are known the main source of government revenue. Besides, tax rates are not changed so often by governments. Thus, it can be said that departures of the effective tax rate from the permanent government expenditure are mostly temporary, and this is not violating the tax smoothing hypothesis.

Tax smoothing implies that budget imbalances can be optimal fiscal policy responses to anticipated future events. If a government expects an increase in expenditure, then it can minimize the distortionary effects of the funding the expenditure by imposing some associated tax increase; the optimal policy is a budget surplus or a smaller deficit in this case. If there is an expectation of decreases in expenditure, a budget deficit or a smaller surplus is the optimal policy. (Cashin, et.al, 1999) The empirical results in this paper support this optimal fiscal policy by confirming the presence of the tax smoothing for the period of 1950-2012. The model in this paper indicates that the tax rate is adjusted subsequently in response to the permanent shifts in the government expenditure rate. Thus, it can be said that the government is likely to design the fiscal policy to minimize and spread the welfare loss of taxation. 


\section{References}

- Abel, 2005. "Optimal taxation when consumers have endogenous benchmark level of consumption", Review of Economic Studies, 72, p.21.

- Adler, 2006. "The tax smoothing hypothesis: evidence from Sweden, 1952-1999”, Scandinavian Journal of Economics, 108, p.81.

- Barro, 1979. “On the determination of public debt”, Journal of Political Economy, 87, p.940.

- Beveridge and Nelson, 1981. "A new approach to decomposition of economic time series into permanent and transitory components with particular attention to measurement of the business cycle", Journal of Monetary Economics, 7, p.151.

- Bohn, 1990. "Tax smoothing with financial instruments”, American Economic Review, 80, p.1217.

- Cashin, Haque and Olekalns, 1999. "Spend Now, Pay Later? Tax smoothing and fical sustainability in Soth Asia”, IMF Working Paper, WP/99/63.

- Davis and Fabling. 2002. "Population ageing and the efficiency of fiscal policy in New Zealand", Treasury Working Paper Series, 02/11, New Zealand Treasury.

- Fleurbaey and Maniquet, 2006. "Fair income tax", Review of Economic Studies, 73, p.55.

- Ghosh, 1995. "Intertemporal tax smoothing and government budget surplus: Canada and the United States," Journal of Money, Credit and Banking, 27, p.1031.

- Hamilton, 1994. Time Series Analysis, Princeton University Press, Princeton, NJ.

- Huang and Lin, 1993. "Deficits, government expenditures and tax smoothing in the United States: 192988," Journal of Monetary Economics, 31, p.317.

- Kydland and Prescott, 1977. "Rules rather than discretion: the inconsistency of optimal plans", Journal of Political Economy, 85, p.473.

- Lusinyan and Thornton, 2009. "The sustainability of South African fiscal policy: a historical perspective", Applied Economics, 41, p.859.

- Lusinyan and Thronton, 2011. "Unit roots, structural breaks and cointegration in the UK public finance", Applied Economics, 43, p.2583.

- Pasten and Cover, 2011. "Does the Chilean government smooth taxes? A tax-smoothing model with revenue collection from a natural resource", Applied Economics Letters, 18, p.421.

- Rajaguru and Abeysinghe, 2008. "Temporal aggregation, cointegration and causal inference”, Economics Letters, 101, p.223.

- Reitschuler, 2010. "Fiscal policy and optimal taxation: evidence from a tax smoothing exercise", Scottish Journal of Political Economy, 57, p.238.

- Sahasakul, 1986. “The US evidence on optimal taxation over time”, Journal of Monetary Economics, 18, p.251.

- Serletis and Schorn, 1999. "International evidence on the tax- and revenue smoothing hypotheses", Oxford Economic Papers, 51, p.387.

- Shin, 1994. "A residual-based test of the null of cointegration against the alternative of no cointegration", Econometric Theory, 10, p.91.

- Sims and Watson, 1990. "Inference in linear time series with some unit roots", Econometrica, 55, p.1035.

- Strazicich, 2002. "International evidence of tax smoothing in a panel of industrial countries", Applied Economics, 34, p.2325.

- Watson, 1986. "Univariate detrending methods with stochastic trends", Journal of Monetary Economics, 18, p.49. 